Meta

Journal des traducteurs

Translators' Journal

\title{
From Thumbelina to Winnie-the-Pooh: Pictures, Words, and Sounds in Translation
}

\section{Riitta Oittinen}

Volume 53, numéro 1, mars 2008

Le verbal, le visuel, le traducteur

The Verbal, the Visual, the Translator

URI : https://id.erudit.org/iderudit/017975ar

DOI : https://doi.org/10.7202/017975ar

Aller au sommaire du numéro

Éditeur(s)

Les Presses de l'Université de Montréal

ISSN

0026-0452 (imprimé)

1492-1421 (numérique)

Découvrir la revue

Citer cet article

Oittinen, R. (2008). From Thumbelina to Winnie-the-Pooh: Pictures, Words, and Sounds in Translation. Meta, 53(1), 76-89. https://doi.org/10.7202/017975ar
Résumé de l'article

Même si pour les traducteurs, les mots sont un outil, les textes à traduire contiennent souvent des images, des sons et du mouvement : c'est notre constatation de départ. En d'autres termes, les traducteurs ont besoin de compétences dans les médias. Nous discuterons également des livres d'images et des films en nous servant de différentes adaptations de Disney et d'Andersen. De plus, nous réfléchirons à des questions telles que le texte et la situation, ainsi que l'interaction des informations verbales, visuelles et auditives dans le contexte de la traduction. 


\title{
From Thumbelina to Winnie-the-Pooh: Pictures, Words, and Sounds in Translation
}

\author{
RIITTA OITTINEN \\ University of Tampere, Tampere, Finland \\ riitta.oittinen@uta.fi
}

\begin{abstract}
RÉSUMÉ
Même si pour les traducteurs, les mots sont un outil, les textes à traduire contiennent souvent des images, des sons et du mouvement: c'est notre constatation de départ. En d'autres termes, les traducteurs ont besoin de compétences dans les médias. Nous discuterons également des livres d'images et des films en nous servant de différentes adaptations de Disney et d'Andersen. De plus, nous réfléchirons à des questions telles que le texte et la situation, ainsi que l'interaction des informations verbales, visuelles et auditives dans le contexte de la traduction.
\end{abstract}

\begin{abstract}
The starting point of my article is that even though words are translators' tools, the texts they translate often include images, sounds, and movement, too. In other words, translators need media literacy. In the following, I discuss translating picturebooks and films, using different retellings of Disney and Andersen as examples. In addition, I ponder on issues such as text and situation as well as the interaction of the verbal, visual and aural information in the context of translation.
\end{abstract}

\section{MOTS-CLÉS/KEYWORDS}

picturebooks and films, retelling, verbal, visual and aural, Disney and Andersen

Translator is like the fabricating fox fabulist of fables: swiftly and wittily she moves from one position to another and keeps out of sight with all her five senses open and ready. (Oittinen 2004)

\section{Introduction}

In translation studies the focus primarily lies on the verbal text. Yet even though words are certainly translator's tools, the actual text to be translated more and more often contains images, sounds, and movement. Especially when films and TV programmes are translated or technical documents are created, the translator needs to ponder on issues like the verbal, visual and aural entity and the role of its elements. Interpreters, too, need to pay attention to the body language of the person to be interpreted.

My article deals with images, words, and sounds in the context of translating films and picturebooks. Even if they as genres seem very different, with a closer look, they have much in common. For example, when dubbing films, the translator needs to reflect on the sound; when translating picturebooks, the translator needs to consider on the read-aloud situation and make the translation roll on the aloud-reader's tongue. In addition, both of the genres involve the visual: picturebooks are illustrated and films have set and costume designs. Films and picturebooks ${ }^{1}$ also use similar methods of visual narration, such as panoramas and close-ups; even movement is 
created in a similar manner: the cuts in a film are close to turnings of pages in picturebooks. In film, movement is often created with camera techniques and in a picturebook through design, paralleling colours and shapes and sizes. Film-makers may adopt methods from books and use still pictures in a row to create a continuous story. It is also interesting how the verbs "to hear" and "to see" often compensate each other in everyday life. On the Finnish television I quite recently heard the commentator say: "we are now going to see a concert"; on a recent taxi ride the driver and I were quite at ease to discuss listening to the TV news. As Kai Mikkonen points out, it is often very hard to distinguish between our sense perceptions. ${ }^{2}$

In the following I discuss the situation where images, sounds, and words interact in the context of picturebook and film translation. Toward the end of my article I will also underline the importance of media literacy in translator training. As examples I'm using animated films and picturebook translations of my own, especially my illustration and film Thumbelina based on H. C. Andersen's original as well as Disney's version of Winnie-the-Pooh's Halloween based on A. E. Milne's original and its Finnish-language translation by me. I'm paying special attention to what kind of impact the different versions created by translators, illustrators, writers, and directors have on the different characters in the stories. In other words: how will retelling change characterization in the stories?

At the very beginning of my article I will deal with the concept of text: what does it refer to when being used by translators, subtitlers/dubbers, illustrators, and writers? How should we define a text when translating picturebooks and films?

\section{Text and Situation}

A "text" is one of the key terms in translation studies. On the one hand, translators always interpret texts in a certain context: time, place, culture, ideology, norms, audience, and genre; on the other hand, the translator's interpretation is strongly influenced by the elements of the actual text in translation, the material network of meanings ${ }^{3}$ consisting of verbal, visual, and aural information. All this indicates that in the situation of translation the voices of all the different actors are in constant interaction in the concrete situation of time, place, and culture. In addition, translators need to ponder on the role and the expectations of the audience as well as the performance of the translated text. Experiencing the art, reading a picturebook or seeing a film, is inseparable from the entity of a book or film.

The narratologist Gerard Genette discusses texts in several of his writings and gives categories such as paratexts, peritexts and epitexts. Paratexts are divided into peritexts (the concrete parts of the text: paper, cover, headings) and epitexts (book/ film reviews, diaries, letters). According to Genette, a work of art is a combination of peritext and the actual story; a text is a part of a work of art excluding anything paratextual. In other words, a text does not begin with a motto or introduction but the very first word of the actual story. Thus, according to Genette, the actual story of Charles Dickens' Little Dorrit does not begin with the introduction, preface, contents, characters, or title of the story but with the very first words: "Thirty years ago, Marseilles lay burning in the sun, one day."

Yet the division into different kinds of texts is not as clear cut in real works of art such as Maurice Sendak's classic picturebook Where the Wild Things Are telling 
about a little boy Max who gets angry with his mom and sails away to the land "where the wild things are." 5 The title of the book is not only found on the book cover and the front page but is constantly repeated throughout the book: in other words, the title of the book is already part of the storytelling, the first "repetition" of the phrase. The book cover with the title and the pictures of the monsters, also give the reader the first impression of the story, which certainly influences what the reader will expect. In this case, the book cover and the title are already parts of the storytelling.

Even at the first encounter, the visual has a strong impact on defining a text (original text, translator's text). For example, the visual of a picturebook contains, in addition to the actual pictures, the cover, size and shape of letters, layout, quality of paper, and the whole visual design. The visual of a film also includes side materials, trailers, posters, and DVD covers. The cover picture has a special influence on understanding the book/film: a cover shows the main characters, the surroundings, and the atmosphere.

A cover also contains intertextuality and cultural issues. For example, J. K. Rowling's Harry Potter has different covers aimed for different audiences, children and adults. As for Disney, the covers of Cinderella in a book form depict a character that is the spitting image of its original in the film. This allows the reader/viewer to recognize the character and expect a similar story. In every case a cover is part of the work of art. As Kaisu Rättyä, the Finnish scholar in children's literature, points out, a book is not created solely by its writer (and illustrator) but the editor and the publisher are among the creators of the book as a product.

Peritexts also have a close connection to canonization: when works of art becomes classics, even their peritexts may change. ${ }^{6}$ Again Sendak's Where the Wild Things Are with its numerous translations serves as a good example. When new Germanlanguage editions of the book appeared, the cover remained the same but a reference was added to the book's history and the author's other works, tempting the reader to buy and read the book. On the other hand, when books become films they may get quite new covers, as did L. M. Montgomery's Anne of Green Gables. After the film series appeared, the original story was reprinted as a book with a new cover depicting the actor in Anne's role. Classic books may also keep their covers through ages, like the Finnish author Väinö Linna's Under the North Star (Täällä pohjan tähden alla 1-3), the Finnish classic work depicting Finnish history through decades as experienced by one family. ${ }^{7}$ The work has kept its original cover ever since it was first published in 1959-1962.

Another example of what a book cover tells about its creators' intentions is Aldo Busi's Italian-language translation Alice nel paese delle meraviglie (2005) of Lewis Carroll's Alice's Adventures in Wonderland. Unlike other Alice translations, the cover of Busi's translation is a painting, A Good Book by Walter Firle. The picture shows three little girls (maybe Carroll's "the cruel Three") absorbed in reading an - undoubtedly - good book. Maybe the editor or translator has wanted to say that this very book is a good one, or maybe s/he has only wanted to underline the importance of reading as such. What is also interesting in this very book is that the English original runs on the left-hand side and the Italian translation on the right. In this way, the position of the original is strengthened and the reader may even check things in the original, which is not that far removed from showing films with subtitles. 
Moreover, as to the visual, it is very interesting to see that all the original pictures by John Tenniel except for one have been deleted. At the very beginning of the Italian translation there is only one big picture depicting the trial of the poor soldier who ate the cakes. In addition to the soldier standing in the forefront, the reader can see the Queen and King of Hearts, the White Rabbit as well as some other creatures appearing at the trial (the jury). The name of the illustrator is not mentioned anywhere in the book - maybe because all the other pictures have been deleted. Yet the influence of this one picture is strong and, on the basis of the picture, the reader expects a story situated in some part of the $19^{\text {th }}$-century England. However, the reader's expectations are not fulfilled but the translation is in many ways moved closer to the present-day Italy. For example, there are references to Italian food (pasta), religion (Alice says "Amen" and the Hatter says: "sono un povero cristo," I'm a poor Christian) and Italian celebrities like Mike Buongiorno (in the poem Father William "Mike" and "quiz" are mentioned). There are also references to present times such as "Siamo già nel Terzo Millennio!" (we're living in the third millenium). Thus in several ways the visual of the book reflects the aims of the creators of the Italian version. The story has been domesticated in time and place, which stands in contradiction with the picture by Tenniel representing the $19^{\text {th }}$-century British culture: the picture makes the reader expect something else than the Italian culture in the $21^{\text {st }}$ century, which makes the characters in the Italian version less believable, whether intended or not. ${ }^{8}$

As the above example shows, a "text" is not easy to define, especially in the context of translation. The word "text" may refer to the verbal only or the verbalvisual-aural entity of originals and translations; "a text" may also refer to the whole intertextual world of texts that the translator is exploiting when creating the translation. Moreover, in the Finnish language, the word "text" (teksti, tekstitys) may even refer to the subtitles of a film. In film translation, it is often necessary to define visualverbal and aural-verbal texts: the first signifies subtitles (which is part of the visual entity) and the latter the dialogue and speaker's/actor's voice.

The texts themselves may also interact and concretely refer to each other. For example, translating the Finnish picturebook creator Mauri Kunnas' Koirien Kalevala (1992, The Canine Kalevala 1992) into English proved problematic, because the whole idea of the book is based on the Finnish national epic The Kalevala and many of the pictures, too, are comical adaptations of The Kalevala pictures by Axel Gallen-Kallela, for Finns the canonized Kalevala illustrator. The book also includes culture-specific references to Finnish culture (bathing in the sauna) and the Finnish countryside (woods).

In addition, the translator's own life-long experience and all the texts s/he knows are present in the act of translation. Translators are also readers, situated in time, place and culture, and anything they have read or experienced has an influence on how they translate. In this article, I'm mainly using "a text" in the sense of an iconotext, (picturebook, film), a combination of the verbal, the visual, and the aural. ${ }^{9}$

\section{Andersen and Disney}

In the following, I present as examples two sets of stories, Thumbelina and Winniethe-Pooh, which both have appeared in the form of picturebooks and films. In both 
of them, the verbal, the visual, and the aural are being used to create an illusion: the reader/viewer is tricked into believing in the story and the characters.

In both of the examples, the characters (people, animals, objects) are characterized in a certain manner. In other words, characterization is based on the verbal, visual, and aural information given in the story. The character has a certain kind of a disposition and temperament and a certain kind of looks; the character has a certain background, s/he speaks in a certain way and is given a certain name, which is why certain things happen to her/him. ${ }^{10}$ Even the actor adds to the characterization and changes the character by giving her/him/it a certain voice. Moreover, the media used have an influence on the characterization. For example, in a book a person may be characterized by words; in a film the same person may be characterized by showing how s/he looks and how s/he moves. In other words, one element replaces the other.

In his book Motion Pictures. The Development of an Art (1980) A. R. Fulton uses the term "substitution" to describe what happens when books become films. According to Fulton, books and films may tell similar stories employing different means. For example, while a novel portrays wide scenes by using words extensively, a film may replace tens of pages of verbal description by painting scenes with music and wide visual panoramas. Fulton discusses Charles Dickens' Great Expectations in a book (1860-61) and a film format directed by David Lean (1946), especially the description of the Cooling Marshes in East Kent. According to Fulton, Dickens depicts two childhoods: his own poverty-stricken childhood and the main character Pip's miserable childhood. As Fulton says, "He [Dickens] refers to them again and again, not just for the sake of description but for projection of character." In the same vein the director uses descriptions of the marshes. In other words, even though a film may not - in the manner of style - follow the book, "it can remain true to it in other ways."11 Again, one means replaces the other.

In the following examples I discuss substitution, intertextuality, characterization, and how they all have influenced the solutions of the retellers and the translators of the stories.

\section{Retelling Andersen}

H. C. Andersen's fairytale Thumbelina appeared for the first time in 1835, and it has been retold and translated over and over again. There are also several films and comics based on the story.

The story begins with introducing an old woman who wants a child and goes to a witch for help. The witch gives the woman a barleycorn, which is planted in a pot and grows into a beautiful tulip-like flower with a lovely little girl, Thumbelina, inside. Thumbelina is happy in her home with her mother, but one night she is snatched away by two ugly toads. The younger of the toads wants to marry Thumbelina but she manages to escape. After several adventures she spends her summer in the woods, but when winter comes she is about to die in the freezing cold. Finally, Thumbelina finds her way to the Field Mouse's den, where she stays over the winter nursing a sick swallow. Every day Thumbelina meets the Mole, the Mouse's friend, who falls in love with Thumbelina and wants to marry her. This time it really seems that she has no escape. Then the Swallow steps in, now fully recovered, and takes her 
far away to the south, to a beautiful warm country, where the story has a happy end: Thumbelina finds a fine little prince, about her own size, who makes her very happy. Thumbelina gets married with the prince and changes her name: she becomes Maia, the queen of flowers.

In 1979 the story was translated into Finnish by Meri Stark and illustrated by me. The book was a co-print and appeared in several languages at the same time. In practice this meant that there were quite a few restrictions to my work as an illustrator. First of all, there was a certain layout and a certain space reserved for my pictures. I also had to follow the translation very closely, and I felt that my hands were tied. In 1994 the Finnish Broadcasting Company showed my ten-minute film Peukaloliisa (Thumbelina), which was part of a series of four Andersen's stories created by me for television. This time I translated the text myself, I created the illustrations and storytelling and also directed the actor in his roles depicting the characters. Even though the basic story remained the same, I was now more able to retell the story myself. What I really wanted to do was to change the characterization.

In Andersen's original story the Mole and the Field Mouse are very selfish. They neglect Thumbelina's distress about having to stay underground the rest of her life and not seeing the sun any more. Thumbelina has no choice: she doesn't know how to say no and feels obliged to obey and consent to marriage. As I have always been irritated by Thumbelina's exaggerated sweetness, I wanted to change her in my film into a more modern character with the will of her own. I based her character in part on the looks of the girl, in part on her behaviour, her speech and acts. In the film version, looking straight into the viewer's eyes, Thumbelina says a clear no: "No, I will never marry the Mole, because I do not love him.” The Swallow's character changes, too: in my version the Swallow is male, not an "it" ("den" in Danish) as in H. C. Andersen's original story. ${ }^{12}$ Yet the Swallow and Thumbelina are close friends in both of the stories. The actor Ola Tuominen gave the Swallow the air of an older gentleman, who is widely travelled and knows about the world. Through his low voice, the Swallow gets more exotic and refined.

The creative processes of illustrating the book and making the film were very different. While drawing the pictures, I did not have many options; as the creator of the film, I had almost free hands. In the film I also used several aural and visual effects in substitution of the verbal descriptions of the original text. When the autumn comes, one can hear the wind and see the leaves flying through the air. In one scene, where the Swallow enters, one can hear the sound of the wings first and the actual bird a bit later. In this way the viewer is made to expect the bird to enter. Music, too, is important: it gives a certain atmosphere and begins and closes the storytelling. Some scenes are only told by using visual elements; some scenes are based more on the sound. In other words, the verbal, visual, and aural take turns and are all part of the characterization of the story.

\section{Retelling Disney}

Disney films are apposite examples of intertextuality. At first appears the original story, such as the Grimm Brothers' Cinderella, which is turned from a book into a film. Then appears another book, now based on the Disney film, which is followed by a new film, Cinderella 2, based on the cast of characters of the original book and 
the first film. This process of combining something old and something new goes on as long as there are people interested in the characters and the stories tied around them. The characters are often detached from their original contexts and lead new lives, like the princesses in the Disney comic series Princess Stories, where Snow White, the Sleeping Beauty, Cinderella, and Belle all appear together. The series includes moralistic stories such as "Beauty Shines from Within," "Tales of Friendship," and "A Gift from the Heart"; there are even programmes and additional DVD materials where little girls are given instructions on how to be and act like real princesses.

In the retellings the princesses' characters gradually change: they become mere vehicles of stereotypical beauty, and it is hard to tell one from the other except for the colour of their hair. In the Grimm Brothers' original story Cinderella, things happen to the girl, because she has a certain character: she is honest, God-fearing, and humble, which were virtues in the Grimmian times. Because Cinderella is good, birds and other animals help her in the difficult tasks given her by her evil stepmother. In the Disney film versions Cinderella is more versatile: she still has her good nature and love for animals, but she also has a sense of humour and she is even able to laugh at the creatures' caprices. Birds and mice help her, but she knows how help herself, too. ${ }^{13}$ What both of the stories have in common is the happy end.

In the following I take a closer look at one more classic turned into films by Disney: A. A. Milne's Winnie-the-Pooh stories. Winnie-the- Pooh first appeared in When We Were Very Young (1924), but the first actual Pooh story, Winnie-the-Pooh appeared in 1926. The Pooh stories tell about the friendship of Christopher Robin and Winnie-the-Pooh and are situated in the Hundred Acre Wood, where Pooh lives with his other friends Piglet, Owl, Tigger, and Eeyore. The Pooh bear is eager to eat and always hungry, which is why several things happen to him: he's stuck in the door hole of Rabbit's house, and he is carried away by a balloon in trying to steal the bees' honey. As to the other characters, Tigger is noisy and bouncy, Eeyore is a sad pessimist, Piglet is always afraid and uncertain about himself, and Owl pretends to be wiser than he is.

There are several kinds of intertextuality in Disney adaptations of original classics: even the different media may loan means and gags from each other. This is the case with the films Winnie-the-Pooh and the Honeytree (1966, based on the first two chapters of Milne's Winnie-the-Pooh Book) and Winnie-the-Pooh and the Blustery Day (1968, based on more than one of Milne's Winnie-the-Pooh books ${ }^{14}$ ), where the same means are used as in the original: letters are washed away by the flood or wiped away with the wind. In the films, the storytelling is based on turning over the leaves of the book. The narrator also carries on with a discussion with the Pooh bear and comments on what happens to him. In this way the narrator takes the role of the aloud-reader of a book and the two media are mixed into a combination of a book and film.

The Disney film Pooh's Heffalump Halloween appeared in 2005. The story mainly tells about two friends, Roo and Heffalump, who go Gobloon (goblin) hunting. The two are the smallest characters of the story and speak in a babylike fashion. This is clearly audible in the Finnish dubbed version and discernible in the Finnish subtitles, too. The story begins with a scene where the Rabbit has gathered big bags of sweets for the Halloween. Pooh's tummy, however, gets very noisy and hungry and he eats up all the sweets. Then Tigger starts telling about the terrible Gobloon living in the 
dangerous parts of the wood and fulfilling the wishes of anyone who catches him. To get one wish - new candies for Halloween - the babies Roo and Heffalump decide to catch the Gobloon. After several adventures, the story has a happy end: it is found that there is no gobloon at all, and Roo's mother Kanga arranges a party for everybody with all kinds of nice things to eat. The film also includes songs, whose tunes are very catchy, and some words are repeated over and over again, such as the Gobloon catchers' song "We're friends forever, we'll be brave together" or the encouragement "Brave together, brave forever." In addition, the film, the big story, includes smaller stories, such as a story about the shy and timid Piglet turning into the fearless and strong Piglet. The small stories are told in certain situations, e.g., Roo tells the story about the fearless Piglet when trying to make his friend Heffalump less frightened.

The characterization in the book and the film formats is very interesting. Tigger, for example, is depicted as a very confident character quick in action and with trouble finding food to enjoy ever since his first appearance in Milne's The House at Pooh Corner (1928). In the film version, ${ }^{15}$ Disney has added to Tigger's talkativeness and bounciness, which makes him a wild and funny creature. In the Disney books written on the basis of the films, Tigger's character changes again to more languid and less bouncy, because certain elements are missing: the movement and the sound created by the actor. On the other hand, the book translator may add "bounciness" to the words Tigger utters, and the reader-aloud may substitute the missing sound and visual movement by vivid eloquent reading.

When I translated the book Pooh's Heffalump Halloween ${ }^{16}$ from English into Finnish, the film was one of the original texts to be studied for the translation, as the book was largely based on the film. After seeing the film first and then reading the English-language book manuscript, I felt confused, because the story in the book felt very different and the characterization therein did not conform with that of the film: the book manuscript was simplified and the characters were flatter and less funny. Sometimes the verbal and the visual in the book were in such a contradiction that it was very hard to follow the story at all, which made me study the film very carefully. In other words, I needed to rewrite and manipulate my translation to make it a logical entity compatible with the pictures. The pictures could not be changed because the translation was to be co-printed with translations into other languages as well as the original. In other words, at the stage of translating the book, I did not have any proper original yet. Moreover, it was difficult to check anything in the pictures of the book manuscript, because the black-and-white drawings were sketchy and no details were shown.

Of course, one reason for deleting many parts of the original story (of the film) was the differences between the two media and the lack of space. The situation was also complicated because the book was a part of a series, where certain problems had been solved in a similar manner. For example, the style of speech of the smallest ones, Roo and Heffalump, is quite free and childlike in the original soundtrack as well as the Finnish dubbed and subtitled versions. Yet in the book form, no colloquialisms are used. For example, the little ones say in the Finnish dubbed film: "me mennään" (we go, colloquial) and in the book "me menemme" (we go, more formal). The small difference has a strong impact on the characters' age: in the film versions, Roo and Heffalump speak differently, which makes them clearly smaller than their friends, even Pooh Bear. In the book version they all speak formally and are of the same age. 
In the end, in my book translation all characters speak in a similar manner (Tigger's speech is more alive, though not colloquial either) and there is no age difference between them. This also makes the story lose part of its humor and tension. All in all, Tigger gets less funny, Pooh less greedy, Eeyore less sad, Rabbit less serious, and Piglet less frightened.

What is important here is that through verbal, visual, and aural storytelling as well characterization illusions are created, illusions of certain kind of fellows doing certain kind of things. As the above example shows it is sometimes very problematic to make the film and book versions compatible with each other, which also has a great impact on how believable the characters are from the reader/viewer's point-of-view.

\section{Image, Word, and Sound}

The interaction of the verbal and the visual has been described in a number of ways and the verbal and the visual may have several functions. Through doubling or paralleling, the pictures may support the words, and the other way around. Images may also go in opposite ways and stand in contradiction: through deviation, they veer away from the story told in words; words and pictures may also appear simultaneously, side by side, or they may take turns. In every case, the visual of a story always adds to the storytelling by giving extra information: details about setting in time, place, culture, society as well as characterization and the relationships between the characters. The visual details of a story give a background and place the characters in homes and milieux. As a whole, the visual information always complements and amplifies the verbal narration. ${ }^{17}$

It is often said that while an image is immediate and refers to space, a word refers to time and depicts and creates entities. The relationship of words and images has also been described as echoing: words and images stand in a dialogue and respond to each other. In films and picturebooks words and images have different means and tasks and they may take different roles. We may also tell stories using pictures only or sounds only, but in the end, stories are always recreated in interaction with the reader/viewer/listener. ${ }^{18}$

The relationship of the verbal and the visual might also be described through the strategies of domestication or foreignization. Through domestication, illustrations may add to a smooth entity and bring the story closer to the target-language reader. It may also happen that the illustration in a book is so strange or foreignized that the reader may find the story hard to accept or understand.

One way of approaching the relationship of the verbal and the visual is semiotics. A picture in a picturebook or a picture or even a sound in a film can be depicted as an icon referring to something in the real world; a word in a book (read aloud) or film can be depicted as a symbol based on an agreement. In other words, we need to learn how to call, for example, a cat in different languages. ${ }^{19}$ There is also an indexical relationship between the two: the verbal (like written or spoken words) refers to the visual (illustrations, scenes) and the other way around. In a work of art the visual can be understood as the reason for the verbal and the other way around. Of course, the indexical relationship varies from book to book, film to film, page to page, scene to scene, which is fundamental in understanding a picture book and film and their narration. 
Günther Kress and Theo van Leeuwen (1996) apply semiotics as well as M. A. K. Halliday's grammar to reading images. Their visual grammar is based on the idea of pictures having same kind of regularities and liabilities as words. Using the visual grammar, it is possible to analyze images and their relationships to words. Pictures visualize and conceptualize the story: they include activities, which have a certain purpose; they also give information about the relationship of the characters or things appearing in stories. Using Kress and Leeuwen's terminology, books and films may be described as multimodal texts using "more than one semiotic code."

Films and books are very versatile. They may be multicolour or black and white; they may include scenes with characters speaking in total darkness or they may include silent scenes or page openings. Silences may even be characteristic of some storytellers, such as the Finnish film director Aki Kaurismäki; Sendak's picturebook Where the Wild Things Are also has silent page openings depicting the nightly rumpus of Max and the wild things. Thus it is utterly important for the translator to recognize the different ways of using words, sounds, pictures, spaces - anything within a work of art. All these details carry important information about the story and characters; all these details also create certain rhythms of storytelling. Moreover, in both genres styles and techniques may be combined: realism and surrealism, caricature or comics. The director, editor, illustrator, writer, and translator all have an influence on the entire work of art.

Despite the differences, the sound has similar functions and relationships with the verbal narration as the image. A sound, too, may contradict with the verbal and visual information or corroborate the story. For example, if a giant speaks in a loud booming voice, s/he is believable and creates a frightening atmosphere; if the same giant speaks in a high-pitched or squeaking voice, s/he becomes comical and less frightening. In my film series Matti ja Peikko (1993, 1995, Matti and Goblin), based on Finnish folk tales, the big Goblin speaking in a very loud voice is rather frightening compared with Matti's tiny voice and body. In this case, the verbal and the aural support each other.

Moreover, through sounds different atmospheres, such as suspense and humour, are created. Like images, sounds, too, make the reader/viewer pay attention to certain details in the storytelling. The Finnish scholar Pekka Karjalainen deals with the focal point of attention ${ }^{21}$ : with sounds it is possible to strengthen or weaken anything in the picture, such as walking in the street. By strengthening the sound of the steps the walking as an act as well as the person walking become important; by weakening the sound of the steps, the city and the atmosphere become more important. Jacques Tati often used this technique in his Monsieur Hulot films thus underlining the comical effect of the gags. ${ }^{22}$

There are many kinds of natural and machine sounds: machine sounds may be, for example, humming of engines or noise of cars; natural sounds may be sounds of wind or waves or human sounds like cry, laughter or yawning. Human speech also has characteristics such as tone and intonation, which all have an influence on how the entity is received. Lip synchrony, very important in creating a believable character, often causes problems in dubbing animated films. For example, even though the Finnish version of Pooh's Heffalump Halloween was professionally created by the director, translator and actors, the English-language words are easy to read on the lips, even though the characters are heard to speak Finnish. In other words, in this case, the 
visual contradicts with the verbal. In some animated films, such as cut-out animations, the movements may be more stylized compared with smoothly drawn or computerized films and the lip synchrony may not be a problem. As a whole, creating a plausible entity and fooling the viewer into believing is of great importance.

In addition to creating backgrounds and placing the story in time and place, sounds may also depict certain doings such as brushing the teeth or certain noises such as slamming a door. A special effect often adds to the believability of a scene and creates a character. For example, in spite of being cut out of cartoon, my Goblin became big and powerful through the heavy thumping of his feet. Special effects and music also create continuity to the storytelling by combining different scenes. In my film Tyttö ja talvi (1990, Girl and winter) Luigi Boccherini's music combines the succession of small separate events and changes in nature into a soft shift from winter to spring. All in all, the aural, the visual, and the verbal influence the storytelling and the real viewing situation. With music one can also create different atmospheres and the use of scary music may change an ordinary walk in a corridor into something very frightening (see, e.g., Stanley Kubrick's The Shine).

All in all, reading a book is not far removed from experiencing a film. Reading a book and watching a film are both seeing and hearing: in addition to the verbal and visual information (in picturebooks), the aural is there, too, as (children's) books are read aloud. When a film is subtitled, even the verbal text becomes visible. When seeing a film or reading a book, the viewer concentrates, looks and listens and draws conclusions on the basis of everything experienced.

\section{The Verbal, Visual, and Aural in Translation}

Texts do not say everything, as Shlomith Rimmon-Kenan has pointed out. Their readers need to fill in information gaps found in texts on the basis of their background knowledge as well as their experience. ${ }^{23}$ Due to differences in languages and cultures, loss and gain are necessary parts of translation, too. Sometimes translators simply need to domesticate, expand and explain, to make the translation more accessible to the target-language readers. In translating illustrated texts, such as picturebooks and films, the information coming from many different sources makes it easier for the translator to understand and interpret the story. Yet the abundance of information may cause problems by tempting the translator to fill in the information gaps for the reader.

A good example of the problem illustrated works may cause for translators is John Burningham's Granpa (1984), which depicts the relationship of grandpa and his granddaughter by using short text fragments and full-colour as well as sepia pictures. In the first German translation, the translator destroyed the idea of the book by "explaining" the story to the reader and adding to the continuity of the story. The translator did not have faith in her reader and did not see "the relationship between the fragmentary text and ... the pictures...," which "are as important as whether the book is read in a conventional sequence or not," as Peter Hunt points out. ${ }^{24}$

Justa Holz-Mänttäri underlines the translator's status as professional. ${ }^{25}$ To be able to translate films and picturebooks, translators need visual - or rather - media literacy. Media literacy may be something ordinary, something we learn very early (such as messages containing ideologies and having social consequences); media 
literacy may also refer to something more professional, something one can be trained for. As professionals, translators need determined focussing on details and entities as well as need deep and vast knowledge of different styles and techniques, periods and epochs of time and mental history, typography, styles, lines and colours, shapes and sizes, sound effects and verbal, visual and aural citations and allusions, which are sometimes hard to recognize. ${ }^{26}$ Translators need to recognize cultural differences and figure out, for example, how the use and symbolism of colours changes from culture to culture. All in all, translators need to understand the flow of narration, the ways how the verbal, visual, and aural information create tensions between details and form entities in unique works of art.

\section{NOTES}

1. Compare with comics, see Kaindl $(1997,1999)$.

2. Mikkonen (2005: 24-27).

3. See Lehtonen in Oittinen et al. (forthcoming).

4. Dickens (1994: 1).

5. See Lanes (1980).

6. See Genette (1997: 24-26) and Rättyä (2001: 177-193).

7. See, e.g., Linna <http://www.iblist.com/series1382.htm>.

8. Carroll (2005). Grazie per questo esempio per tutta la familia Galletti, espezialmente Chiara Galletti. I contacted the translator Aldo Busi in November 2006 but received no reply.

9. Rättyä (2001: 177-193) and Oittinen (2004: 35). Chamberlain (1990: 163).

10. Bertills (2003: 51), Oittinen (2004: 101-104).

11. Fulton (1980: 186, 182-195).

12. In the 1983 (1889) English-language edition the swallow is first presented as a "he" and toward the end of the story as a "she," nesting on a tree. The swallow's sex changes from translation to translation. In Jean Hersholt's English translation the swallow is a "he." In the Finnish language there is only one "hän" referring to both sexes, which makes the swallow more neutral. Thank you to Sisko Ylimartimo and Päivi Heikkilä-Halttunen.

13. <http://disney.go.com/princess/html/main_iframe.html>.

14. Pooh in Wikipedia.

15. Tigger also has a film of his own, The Tigger Movie, which appeared in 2000.

16. The Finnish translation appeared in 2006.

17. See Oittinen (2003), Schwarcz (1982: 14-16) and Lewis (2001: 31-45). See also Nikolajeva and Scott (2001).

18. See, e.g., Uspenski (1991: 115B116), Rhedin (1992: 128), Herkman (1998: 49), Jakobson (1987: 469).

19. See Peirce (2001: 415-440).

20. Kress et al. (1996: 183).

21. Karjalainen (1998) and <http://www.aanipaa.tamk.fi/>.

22. See, e.g., Les vacances de Monsieur Hulot <http://us.imdb.com/title/tt0046487>.

23. Rimmon-Kenan (1983: 125-128).

24. The example is given by Emer O'Sullivan (2006: 113-121). Hunt (1991: 183ff).

25. See, e.g., Holz-Mänttäri (1984).

26. For more on reading the visual, see, e.g., Doonan (1993), Evans (1998), Lewis (2001), SachsHombach (2003).

\section{REFERENCES}

Andersen, H. C. (1983): The Complete Illustrated Works of Hans Christian Andersen, London, Auckland, Singapore and Toronto, Chancellor Press.

Bertills, Y. (2003): Beyond Identification. Proper Names in Children's Literature, Åbo, Åbo Akademi University Press.

Carroll, L. (2005): Alice nel paese delle meraviglie, Italian trans. Aldo Busi, Illust. John Tenniel, Milano, Feltrinelli. 
Busi, A. (2006): Letter from Oittinen to Busi.

Dickens, C. (1855-1857/1994): Little Dorrit, London, Penguin Books.

Dickens, C. (1960-1961/1987): Great Expectations, London, Penguin Books.

Doonan, J. (1993): Looking at Pictures in Picture Books, Stroud, Gloucester, Thimble Press.

Evans, J. (ed.) (1998): What's in the Picture? Responding to Illustrations in Picture Books, London, Paul Chapman.

Fulton, A. R. (1980): Motion Pictures. The Development of an Art, Norman, University of Oklahoma Press.

Gambier, Y., Gottlieb, H. (eds.) (2001): (Multi)Media Translation. Concepts, Practices and Research, Amsterdam and Philadelphia, John Benjamins.

Herkman, J. (1998): Sarjakuvan kieli ja mieli, Tampere, Vastapaino.

Holz-MäntтÄri, J. (1984): Translatorisches Handeln. Theorie und Methode, Helsinki, Annales Academiae Scientarum Fennicae, Ser. B 226, Jakobson 1987.

Iser, W. (1978): The Act of Reading. A Theory of Aesthetic Response, English trans. Wolfgang Iser, Baltimore, The Johns Hopkins University Press.

Kainde, K. (1999): "Thump, Whizz, Poom: A Framework for the Study of Comics under Translation," Target 11-2, pp. 263-288.

KaindL, K. (1997): "Warum sind alle Japaner Linkshänder? Zum Transfer von Bildern in der Übersetzung von Comics," TextConText 13-1, pp. 1-24.

Karjalainen, P. (1998): Lecture course at Tampere Polytechnic School of Art and Media.

Kress, G. and T. van Leeuwen (1996): Reading Images. The Grammar of Visual Design, London and New York, Routledge.

Kunnas, M. and T. Kunnas (1992/2002): The Canine Kalevala. English trans. Tim Steffa, Helsinki, Otava.

Kunnas, M. and T. Kunnas (1992): Koirien Kalevala, Helsinki, Otava.

Lanes, S. G. (1980): The Art of Maurice Sendak, New York, Abradale Press, Harry N. Abrams.

Lefevere, A. (1992): Translation, Rewriting, and the Manipulation of Literary Fame, London and New York, Routledge.

Lewis, D. (2001): Reading Contemporary Picturebooks. Picturing Text, London and New York, Routledge.

Mikkonen, K. (2005): Kuva ja sana. Kuvan ja sanan vuorovaikutus kirjallisuudessa, kuvataiteessa ja ikonoteksteissä, Helsinki, Gaudeamus.

Nikolajeva, M. and C. Scott (2001): How Picturebooks Work, London and New York, Garland.

Nodelman, P. (1988): Words about Pictures: The Narrative Art of Children's Picture Books, Athens, Georgia, University of Georgia Press.

O'Connell, E. M. T. (2003): Minority Language Dubbing for Children. Screen Translation from German to Irish, New York, Peter Lang

Oittinen, R. (2004): Kuvakirja kääntäjän kädessä (Translating Picturebooks), Helsinki, Lasten Keskus.

Oittinen, R. (ed.) (2003): "Where the Wild Things Are: Translating Picture Books," in Oittinen, R. (ed.), Translation for Children / Traduction pour les enfants, Meta 48-1/2, pp. 128-141.

Oittinen, R. (2000): Translating for Children, London and New York, Garland.

Oittinen, R. (dir., storyboard, animation) (1994): Peukaloliisa (Thumbelina), Finnish trans. Riitta Oittinen, The Finnish Broadcasting Company.

Oittinen, R. (dir., story, illust., animation) (1993, 1995): Matti ja Peikko (Matti and Goblin), Cut animation series 1-10, The Finnish Broadcasting Company.

Oittinen, R. (dir., story, illust., animation) (1990): Tyttö ja talvi (Girl and winter), Cut animation, Finnish Broadcasting Company.

Peirce, C. S. (1932): Collected Papers by Charles Sanders Peirce, Cambridge and London, Harvard University Press.

Rhedin, U. (1992): Bilderboken på väg mot en teori, Stockholm, Alfabeta, Education Department, University of Art and Design. 
RÄттуё, K. (2001): “Kirjan kansikuva peritekstinä,” in RÄттуё, K. and R. RAussi (eds.), Tutkiva katse kuvakirjaan, Helsinki, BTJ Kirjastopalvelu Oy and Suomen Nuorisokirjallisuuden Instituutti, pp. 177-193.

Sachs-Номвасн, K. (ed.) (2003): Was ist Bildkompetenz?: Studien zur Bildwissenschaft, Wiesbaden, Dt. Univärsitet Verlag.

Schwarcz, J. H. (1982): Ways of the Illustrator. Visual Communication in Children's Literature, Chicago, American Library Association.

Shulevitz, U. (1985): Writing with Pictures. How to Write and Illustrate Children's Books, New York, Watson-Guptill Publications.

DA Silva, I. M. M.. (1991): Das Bild im Kinderbuch und seine Bedeutung für die Translation, Diplomarbeit, Heidelberg, Ruprecht-Karls-Universität.

Uspenski, B. (1991): Kertomuksen poetiikka. Taideteoksen sommittelun periaatteet, Helsinki, Orient Express.

Disney Princess, The Official Website: $<$ http://disney.go.com/princess/html/main_iframe.html $>$.

Hulot, Les vacances de Monsieur Hulot: $<$ http://us.imdb.com/title/tt0046487/>.

Linna, <http://www.iblist.com/series1382.htm $>$.

Pooh in Wikipedia: $<$ http://en.wikipedia.org/wiki/Winnie_the_Pooh $>$.

Thumbelina (Tommelise) by H. C. Andersen: $<$ http://hjem.get2net.dk/chenero/hcaey005_da.html>.

Hersholt's translation of Thumbelina: $<$ http://sdu.dk/vaerk/hersholt/om_e.html>. 